\title{
An annotated type catalogue of the dragon lizards (Reptilia: Squamata: Agamidae) in the collection of the Western Australian Museum
}

\author{
Ryan J. Ellis \\ Department of Terrestrial Zoology, Western Australian Museum, Locked Bag 49, Welshpool DC, \\ Western Australia 6986, Australia. Biologic Environmental Survey, 24-26 Wickham St, East Perth, \\ Western Australia 6004, Australia.
}

Email: ryan.ellis@museum.wa.gov.au

\begin{abstract}
The Western Australian Museum holds a vast collection of specimens representing a large portion of the 106 currently recognised taxa of dragon lizards (family Agamidae) known to occur across Australia. While the museum's collection is dominated by Western Australian species, it also contains a selection of specimens from localities in other Australian states and a small selection from outside of Australia. Currently the museum's collection contains 18,914 agamid specimens representing 89 of the 106 currently recognised taxa from across Australia and 27 from outside of Australia. This includes 824 type specimens representing 45 currently recognised taxa and three synonymised taxa, comprising 43 holotypes, three syntypes and 779 paratypes. Of the paratypes, a total of 43 specimens have been gifted to other collections, disposed or could not be located and are considered lost. An annotated catalogue is provided for all agamid type material currently and previously maintained in the herpetological collection of the Western Australian Museum.
\end{abstract}

KEYWORDS: type specimens, holotype, syntype, paratype, dragon lizard, nomenclature.

\section{INTRODUCTION}

The Agamidae, commonly referred to as dragon lizards, comprises over 480 taxa worldwide, occurring in Africa, Asia, Australia and southern Europe. Within Australia, the family is represented by 106 taxa (98 species and 12 subspecies) within 16 genera (Uetz et al. 2019). Species diversity within Australian genera is highly variable, with the number of taxa within genera ranging from single species to 37 . The highest diversity occurs in Ctenophorus Fitzinger, 1843 (32 spp. +7 subspp.) followed by Diporiphora Gray, 1842 (28 spp.), Tympanocryptis Peters, 1863 (15 spp.), Pogona Storr, 1982 (6 spp. + 3 subspp.), Amphibolurus Wagler, 1830 (4 spp.), Lopognathus Gray, 1842 (2 spp.), Lophosaurus Fitzinger, 1843 (2 spp.) and a number of monotypic genera (Chelosania Gray, 1845, Chlamydosaurus Gray, 1825, Cryptagama Witten, 1984, Gowidon Wells \& Wellington, 1983 [1984], Hypsilurus Peters, 1867, Intellagama Wells \& Wellington, 1985, Moloch Gray, 1841, Rankinia Wells \& Wellington, 1983 [1984], Tropicagama Melville, Ritchie, Chapple, Glor \& Schulte, 2018) (Uetz et al. 2019).

The first Australian agamid was named in 1790 by John White, Lacerta muricata White, 1790 [now Amphibolurus muricatus (White, 1790)] from New South Wales, and the first known to occur in Western
Australia was named by John Edward Gray in 1825, Clamydosaurus kingii Gray, 1825 [now Chlamydosaurus kingii (Gray, 1825)]. Most early taxonomic and nomenclatural work on Australian agamids in the 19th century was undertaken by European researchers, namely John Edward Gray of the British Museum (Natural History) (now Natural History Museum, United Kingdom (NHMUK)), which resulted in little type material for species described during this time being held in Australian Museums. Between 1800-1850, 15 currently recognised taxa were described, of which 14 were by John Gray. From 1851-1900, a further 18 currently recognised taxa were described, contributed by a range of European and Australian authors. An increase in the number of Australian researchers and museum facilities in the 20th century saw a large quantity of agamid species described during this time, with a substantial portion of type material held in Australian collections. Between 1901-1950, 12 currently recognised taxa were described, largely contributed by Francis John Mitchell (5 taxa), Richard Sternfeld (3 taxa) and Arthur Loveridge (2 taxa). In the late 20th century (1951-2000), 41 currently recognised taxa were described. Extensive work by Glen Milton Storr of the Western Australian Museum (WAM) during this period saw a significant increase in the number of described taxa (29 taxa between 1964-1981), mostly from Western 
Australia, with the majority of the type material being deposited at the WAM. Since 2000, the research by the current WAM Curator of Herpetology, Paul Doughty, and colleagues including Jane Melville and Katie Smith Date (Museums Victoria, Melbourne (NMV)) has seen substantial increases in agamid species descriptions (19 taxa). This increase in diversity has resulted from numerous species discoveries and revisionary works of species complexes utilizing genetic data within currently recognised taxa, many of which have some or all type material deposited in the WAM collection.

Since its 1891 establishment, the WAM [originally known as the Geological Museum (1891-1892), then the Public Museum (1892-1895), Perth Museum (1895-1897), Western Australian Museum and Art Gallery (1897-1960 and subsequently the WAM (1960present)] herpetological collection has grown to become one of the largest Australian collections [second only to the Australian Museum, Sydney (AMS)], and one of the largest regional collections in the world, with over 168,000 specimens (as of 5 February 2019). From 1891 through around 1895, all material donated to the WAM was recorded in a donations register (titled '1895 Donations to the Museum'). During the same time, a separate register titled '1895 THE MUSEUM PURCHASES', detailed items purchased by the museum. The earliest entry referring to an agamid specimen in the register titled '1895 Donations to the Museum' is for '1 Lizard (Calotes versicolor)' [current nomenclature of specimen unknown, presumably a Ctenophorus species], from 'Perth', collected/donated by 'M.A.L. Fraser[?]', dated 4 November 1895. Numerous entries prior to this date list only 'lizard', 'iguana' or 'spiny lizard', which may or may not refer to agamid species; however, no further information is provided. The earliest entry of an agamid specimen in the museum purchases register is a dry skin of 'Stellio vulgaris' [current nomenclature of specimen unknown, presumably a Ctenophorus species], collected by 'J.T. [John Thomas] Tunney, from 'Broome' dated 30 June 1896. From 1896-1912, all material donated to, collected or purchased by the WAM, including amphibian and reptile specimens, was accessioned into a series of six hardcopy general catalogues. The earliest documented entry of an agamid specimen into the first hardcopy WAM 'Register 18961900' was 'Moloch, Moloch Horridus', collected/donated by 'Mrs Drummond' with no locality data listed, dated 11 July 1896. Prior to the use of the donations register and general catalogues, many earlier acquisitions by the WAM were published in the local press. The earliest reference to the acquisition of an agamid specimen in the local press was 'Mr Page — a preserved Moloch Horridus, commonly known as the "York Devil", published in the Inquirer and Commercial News on 1 February 1865 (Anonymous 1865) which was donated to the then Swan River Mechanics Institute which was later purchased and added to the Geological Museum in 1892 (subsequently the Public Museum, then Perth Museum) before it became the WAM (Anonymous 1960). The whereabouts of the first specimens referred to in the local press, donations register, or early catalogues is unknown as no registration number or additional specimen information was provided. No specimens matching the limited donor/collector and locality information of the early acquisitions listed above could be identified within the current agamid collection at the WAM and are presumed lost or disposed.

In 1912 a separate handwritten catalogue was established specifically for herpetological specimens, with all specimens accessioned into the collection from this point forward also given a registration number prefixed with ' $R$ ' to denote the herpetology collection and is still in use today. Many specimens from the earlier general hardcopy catalogues were re-catalogued into the newer herpetofauna catalogue and assigned with ' $\mathrm{R}$ ' numbers; however, it is not clear if this was completed for the whole collection. The earliest agamid specimen documented in the WAM herpetofauna catalogue (titled 'R1. 1 TO 2923') is R1, a Moloch horridus, collected/donated by 'Mr Reece' with a street address in Leederville (presumably the collector/donors home address) written in the locality column and an annotation stating, 'from the Goldfields', accessioned by Ludwig Glauert (former Keeper of Biological Collections, Curator, Director and Director Emeritus of the WAM, 1910-1963), dated 7 July 1912 (presumably the accession date). The following three entries (R2-R4) have ditto signs referring to the data for R1, and an annotation associated with R2 states 'Note: two specimens with the same registration number "R2". Separated — R2 and R97222', initialled 'CAS 2008' [Claire A. Stevenson, WAM Technical Officer (Terrestrial Vertebrates), 2004-2013). All specimens formerly registered in the WAM herpetofauna catalogue with ' $R$ ' prefixed registration numbers, including those above, have since been entered into the current electronic herpetological collection database where all new specimens are now accessioned.

As of 5 February 2019, the family Agamidae is represented by 18,914 (c. $11.3 \%$ ) of the 168,179 specimens in the WAM herpetology collection and comprises primarily Western Australian species. The collection contains specimens representing 89 taxa from Australia, in addition to 285 specimens representing 27 taxa from outside Australia. Non-Australian specimens include, 214 from Indonesia (representing eight taxa), 43 from Malaysia (representing 11 taxa), 13 from India (representing four taxa), one from Papua New Guinea, and a single specimen with only 'Africa' presented as locality and three (representing three taxa) from unknown origins. Apart from the Indonesian specimens collected during WAM expeditions in the 1980s-1990s, many non-native specimens have been obtained via Perth Zoo (ex-captive display animals) or quarantine intercepts and lack precise locality data. The majority of agamid specimens are whole specimens fixed in a $10 \%$ formalin solution and stored in a $70 \%$ ethanol solution in addition to a small quantity of alizarin-alcian stained, plastinated, skeletal and skin preparations of some species. 
Over 7,500 type specimens are, or have formerly been, held in the WAM herpetology collection with 824 specimens representing types of 48 agamid species or subspecies (including three currently considered junior synonyms of other taxa): 45 primary types (43 holotypes and two syntypes) and 779 secondary types (all paratypes). The WAM collection contains type material for 45 of the 106 currently recognised species or subspecies occurring in Western Australia. Of the 824 type specimens held in the WAM collection, 43 paratypes are no longer held in the WAM collection, including 19 which have been gifted to other institutions since their designation as type material, one was found desiccated and disposed by former curatorial staff, and a further 23 could not be located in the collection and are considered lost. The WAM published a partial list of type compiled by G. M. Storr annually in the WAM Annual Report from 1960 through 1969, before it was discontinued in 1970 with the intention of publishing a consolidated and complete type list which was never achieved (Anonymous 1961, 1970). The Annual Report type lists presented only primary type material, i.e. holotypes and lectotypes, and occasionally syntypes and neotypes; however, no secondary types were listed. A total of 10 parts of the type list were presented, of which only part 2 (1960-61), part 5 (1963-64), part 7 (1965-66), part 8 (1966-67) and part 9 (1967-68) included agamid material for 16 species or subspecies (Anonymous 1961, 1964, 1966, 1967, 1968). Since the 1969 Annual Report, there have been no further publications on the agamid type material held in the herpetological collection of the WAM.

An audit of the type specimens held in the WAM herpetological collection was initiated to publish a current type catalogue of the material held in accordance with recommendation 72F of the Code (ICZN 1999). Due to the size of the herpetological type collection at the WAM, separate audits were undertaken by family and the type catalogue presented in a series of publications. The first of the series was a type catalogue of the turtles (Testudines: Chelidae) (Ellis and Georges 2015), followed by the frogs (Anura: Hylidae, Limnodynastidae and Myobatrachidae) (Ellis et al. 2017), Gekkota (Squamata: Carphodactylidae, Diplodactylidae, Gekkonidae, Pygopodidae) (Ellis et al. 2018) and varanids (Squamata: Varanidae) (Ellis 2018a). The current type catalogue is the fifth of a series aimed at presenting all type material of amphibians and reptiles held by the WAM and presents the type agamids (Squamata: Agamidae) held in the WAM collection.

\section{METHODS}

Information on type specimens was obtained from the original description and compared with information retrieved from accession data in early specimen registers and the current digital herpetology specimen database in addition to jar labels, personal communications and subsequent publications relating to relevant type material. All type specimens in the collection of the
WAM were examined in addition to any respective label information and notations. Where specimens could not be located in the type collection, extensive searches of the general collection, accession data, original descriptions and other records were undertaken during the audit to locate missing specimens or those lacking data. Type specimens of species that have, since their description, been synonymised and/or resurrected from synonymy with other taxa, or those with type material donated to the WAM since their description are also included. This catalogue was prepared in accordance with the rules, recommendations, definitions and amendments of the International Code for Zoological Nomenclature (International Commission on Zoological Nomenclature 1999, 2003, 2012).

\section{FORMAT}

This catalogue follows the format of previous WAM type catalogues on the turtle (Ellis and Georges 2015), anuran (Ellis et al. 2017), gekkotan (geckos and legless lizards) (Ellis et al. 2018) and varanid (Ellis 2018a) type specimens held in the WAM collection.

\section{ORIGINAL BINOMEN}

\section{Genus species subspecies Author, year}

\section{Original type species citation}

Author, year, title, journal, page(s), [page of description].

\section{Primary type (holotype/syntype)}

Registration number, locality (latitude/longitude), collector(s) and collection date.

\section{Secondary type(s) (paratype/s) (number of types in WAM collection)}

Registration number, locality.

\section{Current nomenclature}

Current generic and specific recognition of the species.

\section{Current status}

Current status and validity of the species, synonymies

\section{Remarks}

Additional information provided on subjects including the history and status of types, location of additional type specimens, ambiguity in type designations and information regarding the synonymy or resurrection of a species or subspecies if necessary and available.

Each taxon is presented by the name provided by the original author(s), followed by the author's name, and year of publication. Species names are given in the exact format in which they were first published. The original type species publication citation follows next displaying the author(s), year, title (of article or book), journal (unless otherwise), page(s) and the page on which 
the species description commences in square brackets ([x]). Primary type (holotype or syntype) information includes WAM registration number, locality, latitude and longitude (in degrees minutes seconds, where recorded to that precision or decimal degrees as provided in the original description), collector(s) name and collection date. Primary type localities and coordinates shown in quotes are those presented in the original published descriptions, including errors. Coordinates presented in square brackets $[\mathrm{x}]$ and lacking quotes have been determined from accession data that was not presented in the original description or subsequently determined based on locality data presented in the description. All dates are presented as day - month - year, month year or year, as presented in the original description or relevant information sources. Secondary types (paratype/s) are displayed showing WAM registration number and locality. Specific locality (latitude and longitude) and collection details (collector and date) are not provided for secondary type specimens. Specimens marked with an asterisk $(*)$ are no longer held in the collection of the WAM, either due to being gifted to another institution, disposal by WAM or loss of specimen. Details of specimens no longer held in the collection are discussed further in the Remarks section of each species where information was available. Current nomenclature and status are only presented where change from the original binomen has occurred such as generic changes, specific amendments, changes to species or subspecies status and synonymy or resurrection from synonymy. Remarks include relevant information on issues and errors from original descriptions, specimens, historical remarks or subsequent publications referring to the species or specimens as well as information relating to the synonymy or resurrection of the species or information pertaining to lost or destroyed specimens. Where known, tissue samples for holotypes are presented with tissue type, storage method and storage location. Secondary type material with tissue samples deposited at the WAM are presented with tissue type and storage method where known. Tissue samples for type material that has been depleted is not presented. Square brackets $([\mathrm{x}])$ indicate corrections or additions of information presented in the original description or subsequent publications. The prefix $\mathrm{R}$ is used to denote registration numbers corresponding to the specimens in the herpetofauna collection of the WAM.

The following acronyms and abbreviations in presenting type information in this catalogue have been used, institution acronyms follow Sabaj (2016).

$\begin{array}{ll}\text { ANWC } & \begin{array}{l}\text { Australian National Wildlife Collection, } \\ \text { Canberra, ACT, Australia }\end{array} \\ \text { AMS } & \begin{array}{l}\text { Australian Museum, Sydney, NSW, } \\ \text { Australia }\end{array} \\ \text { E } & \text { east } \\ \text { ENE } & \text { east-northeast } \\ \text { ESE } & \text { east-southeast } \\ \text { FMNH } & \text { Field Museum of Natural History, Zoology } \\ & \text { Department, Chicago, Illinois, U.S.A. }\end{array}$

HS

$\mathrm{km}$

MCZ Museum of Comparative Zoology, Harvard University, Cambridge, Massachusetts, U.S.A.

mi miles

MMUS Macleay Museum, University of Sydney, NSW, Australia

Mt Mount

$\mathrm{N} \quad$ north

NE northeast

NHMUK Natural History Museum (formerly British Museum (Natural History)), London, United Kingdom

NMV Museums Victoria (formerly National Museum of Victoria and Museum Victoria), Melbourne, Vic., Australia

NNE north-northeast

NNW north-northwest

nr near

NR Nature Reserve

NT Northern Territory, Australia

NTM Museums and Art Galleries of the Northern Territory (formerly Northern Territory Museum of Arts \& Sciences), Darwin, NT, Australia

NTR CSIRO Division of Wildlife Research, Darwin, NT Australia

NW northwest

Qld Queensland, Australia

QM Queensland Museum, Brisbane, Qld, Australia

S South

SE Southeast

SSE south-southeast

SSW south-southwest

SW southwest

SA South Australia

SAMA South Australian Museum, Adelaide, SA, Australia

SE southeast

SSE south-southeast

SSW south-southwest

Stn Station

SW southwest

the Code International Code of Zoological Nomenclature (edition included in citation)

W west

WA Western Australia

WAM Western Australian Museum, Perth, WA, Australia 


\section{ACCOUNT OFTYPE SPECIMENS}

\section{SQUAMATA}

\section{Family Agamidae}

\section{Amphibolurus adelaidensis chapmani Storr, 1977}

Storr, G.M. (1977) The Amphibolurus adelaidensis species group (Lacertilia, Agamidae) in Western Australia. Records of the Western Australian Museum 5(1): 73-81 [80].

\section{Holotype}

R24657, ' $11 \mathrm{~km}$ SSE of Cocklebiddy, WA $\left(32^{\circ} 08^{\prime} \mathrm{S}\right.$, $126^{\circ} 08^{\prime}$ E)', G.M. Storr and A.M. Douglas, 8 October 1965.

\section{Paratypes (15)}

R11368*, Esperance, WA; R24590, 16 km NE Eucla, WA; R24656, $11 \mathrm{~km}$ SSE Cocklebiddy, WA; R29592, 7 km W Holt Rock, WA; R30801, Cape LeGrand, WA; R31172, Madura, WA; R34505, 7 km W Holt Rock, WA; R40752, Lake Magenta NR, WA; R41944, Cape LeGrand, WA; R44435, R44436, North Tarin Rock NR, WA; R44526, Fraser Range, WA; R47363, Red Gum Pass, Stirling Range, WA; R53399, 14 km SSE Cocklebiddy, WA; R53401, 21 km SSE Cocklebiddy, WA.

\section{Current status and nomenclature}

Ctenophorus chapmani, see Melville et al. (2001) for generic allocation and Greer (1989) for specific status.

\section{Remarks}

One paratype (R11368) was not located and has not been sighted in various audits and searches dating back to November 1998, including type audits undertaken between July 2008-February 2010. The specimen is presumed lost.

\section{Amphibolurus barbatus microlepidotus Glauert, 1952}

Glauert, L. (1952) Herpetological miscellanea. II. Some new Western Australian lizards. Western Australian Naturalist 3: 168-170 [168].

\section{Syntypes (2)}

R591-92 [in error, R951-52], 'Drysdale River Mission [Pago], North Kimberley', WA $\left(14^{\circ} 08^{\prime} \mathrm{S} ; 126^{\circ} 43^{\prime} \mathrm{E}\right)$, presented by Rev. Father Salinas, July 1922.

\section{Current status and nomenclature}

Pogona microlepidota, see Storr (1982a) for generic allocation and Badham (1976) for specific status.

\section{Remarks}

The two registration numbers listed by Glauert as 'types in the original description are in error, R591 is specimen of Pseudonaja affinis (Serpentes: Elapidae) and R592 a specimen of Neelaps calonotus (Serpentes: Elapidae) (Ellis 2018b). The correct registrations for the two Pogona microlepidota syntypes are R951-52 (Ellis 2018b).

\section{Amphibolurus caudicinctus graafi Storr, 1967}

Storr, G.M. (1967) Geographic races of the agamid lizard Amphibolurus caudicinctus. Journal of the Royal Society of Western Australia 50: 49-56 [51].

\section{Holotype}

R25914, 'Mt Eveline [40 mi [64 km] E of Warburton Range], WA ( $\left.26^{\circ} 10^{\prime} \mathrm{S}, 127^{\circ} 06^{\prime} \mathrm{E}\right)$ ', G.M. Storr and W.H. Butler, 4 November 1965.

\section{Paratypes (31)}

R15716-17, 13 mi [21 km] NE Mt Eveline, WA; R19488, R25915-38, Mt Eveline, $38 \mathrm{mi}$ [61 km] E Warburton Range, WA; R21999, Granite Spring, $18 \mathrm{mi}$ [29 km] NE Warburton Range Mission, WA; R22037, R22195-96, Windarro Spring, $1 \mathrm{mi}$ [1.6 km] E Granite Spring, WA.

\section{Current status}

Ctenophorus graafi, see Storr et al. (1983) for generic placement and Melville et al. (2016) for specific status.

\section{Amphibolurus caudicinctus infans Storr, 1967}

Storr, G.M. (1967) Geographic races of the agamid lizard Amphibolurus caudicinctus. Journal of the Royal Society of Western Australia 50: 49-56 [51].

\section{Holotype}

R25945, 'Deeba Rockhole, 25 miles [40 km] northeast of Laverton, WA $\left(28^{\circ} 22^{\prime}\right.$ S, $\left.122^{\circ} 35^{\prime} E\right)$ ', G.M. Storr and W.H. Butler, 7 November 1965.

Paratypes (9)

R15725, R22588-89, R25911, Niagara Dam, 7 mi [11 km] SW Kookynie, WA; R22583-84, Mt Morgans, WA; R25946-48, 25 mi [40 km] NE Laverton, WA.

\section{Current status}

Ctenophorus infans, see Storr et al. (1983) for generic placement and Melville et al. (2016) for specific status.

\section{Amphibolurus caudicinctus mensarum Storr, 1967}

Storr, G.M. (1967) Geographic races of the agamid lizard Amphibolurus caudicinctus. Journal of the Royal Society of Western Australia 50: 49-56 [51]. 


\section{Holotype}

R19486, ' 5 miles [8 km] south of Meekatharra, WA

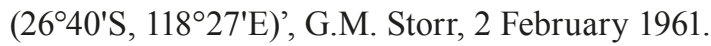

\section{Paratypes (17)}

R13700, Mt Fisher, $110 \mathrm{mi}[177 \mathrm{~km}]$ E Wiluna, WA; R15754, R15771-72, R15790-94, Mileura, WA; R19482-85, 14 mi [22 km] N Meekatharra, WA; R21115-18, Wiluna, WA.

\section{Current status}

Junior synonym of Ctenophorus caudicinctus, see Melville et al. (2016).

\section{Amphibolurus caudicinctus slateri Storr, 1967}

Storr, G.M. (1967) Geographic races of the agamid lizard Amphibolurus caudicinctus. Journal of the Royal Society of Western Australia 50: 49-56 [52].

\section{Holotype}

R26793 (formerly NTM R1471), 'Hermannsburg, NT (2358'S, 13246'E)', K.R. Slater, 11 February 1964.

\section{Paratypes (2) \\ R20869, Hermannsburg, NT; R20902, Alice Springs, NT.}

\section{Current status}

Ctenophorus slateri, see Storr et al. (1983) for generic placement and Melville et al. (2016) for specific status.

\section{Remarks}

Holotype specimen retains former NTM registration tag. Additional paratype specimens are held in other collections: 36 at NTM (NTM R1472-75, R1943, R201819, R2378-96, R2670-79) and one at SAMA (SAMA R3581).

\section{Amphibolurus clayi Storr, 1966}

Storr, G.M. (1966) The Amphibolurus reticulatus species-group (Lacertilia, Agamidae) in Western Australia. Journal of the Royal Society of Western Australia 49: 17-25 [24].

\section{Holotype}

R14462, ' 3 miles [4.8 km] south of Learmonth, WA ( $22^{\circ} 16^{\prime}$ S, $\left.114^{\circ} 06^{\prime} \mathrm{E}\right)$ ', G.M. Storr, 1 November 1961.

\section{Paratypes (13)}

R3944*, between Wells 31 and 36, Canning Stock Route, WA; R3968*, Well 37, Canning Stock Route, WA; R12941-45, R13549*, Queen Victoria Spring, WA; R14463, 5 mi [8.0 km] E Cardabia, WA; R14628, R21998, R22006, R22042*, Warburton Mission, WA.

\section{Current nomenclature}

Ctenophorus clayi, see Storr et al. (1983).

\section{Remarks}

One paratype (R22042) found desiccated and mouldy was disposed on 31 December 1996 and a second (R3944) is marked as being gifted on the WAM herpetology database; however, no further information is provided on recipient or date of gifting. Two paratypes (R3968, R13549) were not located and have not been sighted in various audits and searches dating back to September 1998, including type audits undertaken between July 2008-February 2010; both are presumed lost.

\section{Amphibolurus darlingtoni Loveridge, 1932}

Loveridge, A. (1932) New lizards of the genera Nephrurus and Amphibolurus from Western Australia. Proceedings of the New England Zoölogical Club 13: 31-34 [33].

\section{Paratypes}

R4460 (formerly MCZ 32960), Mullewa, WA.

\section{Current status}

Junior synonym of Ctenophorus reticulatus, see Storr (1966).

\section{Remarks}

The holotype held in the $\mathrm{MCZ}$ collection, $\mathrm{MCZ}$ R32958, from 'Mullewa, WA' [28 $\left.32^{\circ} \mathrm{S}, 115^{\circ} 30^{\prime} \mathrm{E}\right]$, was collected by P.J. Darlington on 21 September 1931. Loveridge designated three additional specimens as paratypes (MCZ R32959-61), all collected from the type locality by P.J. Darlington and I.M. Dixon between 18-23 September 1931. Examination of the MCZ online specimen database (http://mczbase.mcz.harvard.edu/) reveals that one paratype was retained by the $\mathrm{MCZ}$ (MCZ R32959), the second (MCZ R32960) is annotated with 'Ret to Australia' under remarks with a ditto mark below it in the following line associated with the third specimen (MCZ R32961); however, there is no record of which museums the specimens were sent to (José Rosado, personal communication, 2017). Examination of WAM specimen registers reveals only one specimen was registered into the WAM collection, MCZ R32960 (now WAM R4460), 20 September 1932 along with a paratype of Nephrurus wheeleri wheeleri described by Loveridge in the same paper with type material also gifted to the WAM (Ellis et al. 2018). The hardcopy WAM register lists both specimens as accessioned 30 September 1932 and 'Mr A. Loveridge, MCZ Harvard U.S.A.' listed as donor but does not list the original collector or collection dates provided by Loveridge in the original description. A loose tag associated with the WAM specimen with typed and handwritten text, presumably an early MCZ specimen tag, lists the specimens MCZ registration number with 'Amphibolurus darlingtoni Loveridge' with 
'Mullewa' written below it in pencil. At the bottom of the tag, typed text states 'G.M. Allen, P.J. Darlington and W.E. Schevill legit.' and 'Australian Exped. 193132' below it with G.M. Allen and W.E. Schevill crossed out and '22.IX.31' handwritten in pencil, presumably the original collection date of the specimen. Despite the ditto marks associated with MCZ 32961 indicating the specimens was 'Ret to Australia' as for MCZ R32960, the specimen is now held in the NHMUK (NHMUK 1946.9.4.68, formerly NHMUK 1932.7.13.2) (Patrick Campbell, personal communication, 2017).

\section{Amphibolurus femoralis Storr, 1965}

Storr, G.M. (1965) The Amphibolurus maculatus species-group (Lacertilia: Agamidae) in Western Australia. Journal of the Royal Society of Western Australia 48: 45-54 [49].

\section{Holotype}

R17008, '23 miles [37 km] north-east of Giralia, WA (22 $\left.29^{\prime} \mathrm{S}, 114^{\circ} 33^{\prime} \mathrm{E}\right)$ ', G.M. Storr and B.T. Clay, 19 October 1962.

\section{Paratypes (30)}

R9008, Northwest Cape, WA; R17013-18, 9 mi [14 km] NE Yanrey, WA; R17100-04, 4 mi [6 km] W Bullara, WA; R18674-76, 15 mi [24 km] SE Cardabia, WA; R18678-80, $18 \mathrm{mi}$ [29 km] SSW Bullara, WA; R18681-82, 13 mi [21 km] S Exmouth Gulf HS, WA; R18683-84, 6 mi [10 km] S Learmonth, WA; R18685*, $5 \mathrm{mi}[8 \mathrm{~km}] \mathrm{N}$ Learmonth, WA; R18686-92, $9 \mathrm{mi}$ [14 km] NE Giralia, WA.

\section{Current nomenclature}

Ctenophorus femoralis, see Storr et al. (1983).

\section{Remarks}

One paratype (R18685) was not located and has not been sighted in various audits and searches dating back to September 1998, including type audits undertaken between July 2008-February 2010. The specimen is presumed lost.

\section{Amphibolurus fordi Storr, 1965}

Storr, G.M. (1965) The Amphibolurus maculatus species-group (Lacertilia: Agamidae) in Western Australia. Journal of the Royal Society of Western Australia 48: 45-54 [48].

\section{Holotype}

R19151, '12 miles [19 km] north-west of Coolgardie, WA (3049'S, 12102'E)', J.R. Ford, 1 January 1963.

\section{Paratypes (16)}

R12950, 12 mi [19 km] NW Cundeelee, WA; R17336, $18 \mathrm{mi}$ [29 km] SSE Karonie, WA; R18663-70, $12 \mathrm{mi}$
[19 km] NW Coolgardie, WA; R18671, Comet Vale, WA; R18672-73, $10 \mathrm{mi}$ [16 km] E Zanthus, WA; R19148-50, $12 \mathrm{mi}[19 \mathrm{~km}] \mathrm{NW}$ Coolgardie, WA.

\section{Current nomenclature}

Ctenophorus fordi, see Storr et al. (1983).

\section{Amphibolurus isolepis citrinus Storr, 1965}

Storr, G.M. (1965) The Amphibolurus maculatus species-group (Lacertilia: Agamidae) in Western Australia. Journal of the Royal Society of Western Australia 48: 45-54 [51].

\section{Holotype}

R21706, '2 miles [3 km] west of Boorabbin, WA (31 $12^{\circ}$ 'S, 120¹7'E)', G.M. Storr, 11 November 1963.

\section{Paratypes (12)}

R14121, R14125, Dedari, WA; R21710, $12 \mathrm{mi}$ [19 km] E Southern Cross, WA; R21707, $2 \mathrm{mi}$ [3 km] W Boorabbin, WA; R18830-37, 12 mi [19 km] NW Coolgardie, WA.

\section{Current nomenclature}

Ctenophorus isolepis citrinus, see Storr et al. (1983).

\section{Amphibolurus isolepis rubens Storr, 1965}

Storr, G.M. (1965) The Amphibolurus maculatus species-group (Lacertilia: Agamidae) in Western Australia. Journal of the Royal Society of Western Australia 48: 45-54 [50].

\section{Holotype}

R18740, 'Yanrey, WA (22³0'S, 114²4'E)', G.M. Storr and B.T. Clay, 3 November 1961.

\section{Paratypes (30)}

R5009, Mia Mia, WA; R5331, Marilla, WA; R12624, Koordarrie, WA; R13125 (now R176115), R13318, 176-mile Tank, $22 \mathrm{mi}$ [35 km] NE Winning, WA; R16953, Yalobia, WA; R17004-07, 23 mi [37 km] NE Giralia, WA; R17009-12, 9 mi [14 km] NE Yanrey, WA; R17019-20, 4 mi [6 km] E Onslow, WA; R18743, 14 mi [22 km] E Yanrey, WA; R18695-96, R18697*, R18698, 6 mi [10 km] SE Gnaraloo, WA; R18725, 9 mi [14 km] NE Giralia, WA; R18736-39, 16 mi [26 km] NE Winning, WA; R18741-43, Yanrey, WA; R18744, 14 mi [22 km] E Yanrey, WA.

\section{Current status}

Ctenophorus rubens, see Storr et al. (1983).

\section{Remarks}

One registration number listed by Storr (R13125) is associated with two specimens, one a specimen of 
C. rubens and the other a specimen of Parasuta gouldii (Serpentes: Elapidae) with examination of hardcopy WAM herpetological registers revealing the $P$. gouldii specimen was the first to be assigned the number. The C. rubens specimen has been reregistered as R176115. One paratype (R18697) was not located and has not been sighted in various audits and searches dating back to September 1998, including type audits undertaken between July 2008-February 2010. The specimen is presumed lost.

\section{Amphibolurus maculatus badius Storr, 1965}

Storr, G.M. (1965) The Amphibolurus maculatus species-group (Lacertilia: Agamidae) in Western Australia. Journal of the Royal Society of Western Australia 48: 45-54 [46].

\section{Holotype}

R18624, '15 miles [24 km] south-east of Cardabia, WA (23ำ'S, $\left.113^{\circ} 55^{\prime} \mathrm{E}\right)^{\prime}$, G.M. Storr and B.T. Clay, 31 October 1961.

\section{Paratypes (77)}

R16872, 12 mi [19 km] SSE Ningaloo, WA; R16875, R16879, 15 mi [24 km] SSE Ningaloo, WA; R16955-65, $3 \mathrm{mi}$ [5 km] SE Cardabia, WA; R16968, 8 mi [13 km] N Cardabia, WA; R16969-70, $11 \mathrm{mi}$ [18 km] N Cardabia, WA; R16973-74, 14 mi [23 km] N Cardabia, WA; R16983*, 12 mi [19 km] SSE Ningaloo, WA; R16985, 7 mi [11 km] SE Ningaloo, WA; R16986-90, Ningaloo, WA; R17317, 6 m [10 km] S Quobba, WA; R18605-10, Ningaloo, WA; R18611-17, 12 mi [19km] SSE Ningaloo, WA; R18618, 18 m [30 km] SSW Bullara, WA; R1861923, 4 mi [6 km] N Cardabia, WA; R18625, $11 \mathrm{mi}$ [18 km] SE Cardabia, WA; R18626-28, 4 mi [6 km] S Gnaraloo, WA; R18629-35, 18 mi [29 km] N Quobba, WA; R1863741, Quobba, WA; R18642-43, 6 m [10 km] S Quobba, WA; R18644-56, 24 mi [39 km] N Carnarvon, WA.

\section{Current nomenclature}

Ctenophorus maculatus badius, see Storr et al. (1983).

\section{Remarks}

One paratype (R16983) is listed on the WAM herpetological database as gifted with no further information on the recipient of date of gifting and its current whereabouts is unknown. The specimen was not sighted in audits dating back to September 1998, indicating the specimen was gifted prior to then.

\section{Amphibolurus maculatus dualis Storr, 1965}

Storr, G.M. (1965) The Amphibolurus maculatus species-group (Lacertilia: Agamidae) in Western Australia. Journal of the Royal Society of Western Australia 48: 45-54 [47].

\section{Holotype}

R23637, '7 miles [11 km] south-southeast of Cocklebiddy, WA $\left(32^{\circ} 08^{\prime} \mathrm{S}, 126^{\circ} 08^{\prime} \mathrm{E}\right)$ ', G.M. Storr and A.M. Douglas, 8 October 1964.

\section{Paratypes (57)}

R23638-94, 7 mi [11 km] SSE Cocklebiddy, WA.

\section{Current nomenclature}

Ctenophorus maculatus dualis, see Storr et al. (1983).

\section{Amphibolurus maculatus griseus Storr, 1965}

Storr, G.M. (1965) The Amphibolurus maculatus species-group (Lacertilia: Agamidae) in Western Australia. Journal of the Royal Society of Western Australia 48: 45-54 [47].

\section{Holotype}

R21708, '14 miles [23 km] west of Boorabbin, WA

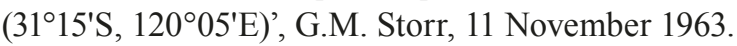

\section{Paratypes (16)}

R2520-23, Ongerup, WA; R5740, Manmanning, WA; R6074, Kunkerin, WA; R10482, Ravensthorpe district, WA; R12296, Dumbleyung, WA; R12616, Tarin Rock, WA; R13140, 8 mi [13 km] W Coorow, WA; R14021*, $10 \mathrm{mi}$ [16 km] S Coorow, WA; R21530, Holt Rock, WA; R21709, $14 \mathrm{~m}$ [23 km] W Boorabbin, WA; R21742, R21743*, R21744*, Lake Magenta NR, WA.

\section{Current nomenclature}

Ctenophorus maculatus griseus, see Storr et al. (1983).

\section{Remarks}

Three paratypes (R14021, R21743-44) could not be located and none were sighted in various audits and searches dating back to September 1998, including type audits undertaken between July 2008-February 2010. These specimens are presumed lost.

\section{Amphibolurus mckenziei Storr, 1981}

Storr, G.M. (1981) Three new agamid lizards from Western Australia. Records of the Western Australian Museum 8(4): 599-607 [605].

\section{Holotype}

R59754, '8 km SW of Ponier Rock, WA (32 ${ }^{\circ} 59^{\prime} \mathrm{S}$, $123^{\circ} 26^{\prime}$ E)', N.L. McKenzie and P.J. Fuller, 1 March 1978.

\section{Paratype}

R59753, 3 km NE Ponier Rock, WA.

\section{Current nomenclature}

Ctenophorus mckenziei, see Storr et al. (1983). 


\section{Amphibolurus mitchelli Badham, 1976}

Badham, J.A. (1976) The Amphibolurus barbatus species-group (Lacertilia: Agamidae). Australian Journal of Zoology 24: 423-443 [435].

\section{Holotype}

R26828, 'Derby, WA' (17²18'S, $\left.123^{\circ} 37^{\prime} \mathrm{E}\right)$, collected by the Department of Public Health, 5 February 1966.

\section{Paratypes (28)}

R13066, [Mt Edgar], Woodstock [Stn], WA; R14135, Broome, WA; R15182, R15183-84, R15823, Derby, WA; R19377, [23 km SE] Mundabullangana, WA; R19566, Mundabullangana, WA; R20078-79, Tambrey, WA; R26828 [in error, holotype], R26829-830, Derby, WA; R27723, La Grange, WA; R31037, R32166, R32187*, R33624, Derby, WA; R31156, R32196-97, Mt Anderson, WA; R112605-12 (formerly part of R14135), Broome, WA.

\section{Current status and nomenclature}

Pogona minor mitchelli, see Storr (1982a) for generic placement and subspecific status.

\section{Remarks}

Badham erroneously listed the holotype as a paratype. One paratype registration number listed by Badham, R14135, included nine specimens, eight of which were specimens were reregistered on 26 July 2002 as R112605-612. Eight additional paratypes held in the SAMA collection (SAMA R1399-400, R1404, R3436, R3546, R4483-84, R9520). One paratype (R32187) could not be located and is presumed lost. The specimen has not been sighted during any previous audits and searches dating back to May 1998.

\section{Amphibolurus nullarbor Badham, 1976}

Badham, J.A. (1976) The Amphibolurus barbatus species-group (Lacertilia: Agamidae). Australian Journal of Zoology 24: 423-443 [440].

\section{Holotype}

R29667, ' 16 km NW of Naretha Railway Station, WA' (3000'S, 12458'E), P.J. Fuller, 4 September 1967.

\section{Paratypes (11)}

R16999 (in error, R16888*), R16896, Forest, WA; R19592, [5 km N] Naretha, WA; R24655, Cocklebiddy, WA; R28127, Wilsons Bluff, WA; R28901, $70 \mathrm{mi}$ [33 km] NNE [NE] Madura, WA; R29486, $10 \mathrm{mi}$ [16 km] S Loongana, WA; R31964-965, $70 \mathrm{mi}$ [112.6 km] NNE, Rawlinna, WA; R36120, 47 mi [75.6 km] S Cook, SA; R39055, $10 \mathrm{mi}$ [16 km] W Seemore Downs, WA.

\section{Current nomenclature}

Pogona nullabor, see Storr (1982a).

\section{Remarks}

Two additional paratypes held in the SAMA collection (SAMA R3547, R5034). One paratype registration listed by Badham (R16999) is in error: the registration number R16999 is associated with a specimen of Gehyra capensis from Shothole Canyon, WA. The correct registration number of a $P$. nullabor specimen matching the locality data provided by Badham is R16888; however, the specimen could not be located and is presumed lost. The specimen was last sighted during a type audit undertaken in May 1998.

\section{Amphibolurus parviceps butleri Storr, 1977}

Storr, G.M. (1977) The Amphibolurus adelaidensis species group (Lacertilia, Agamidae) in Western Australia. Records of the Western Australian Museum 5(1): 73-81 [75].

\section{Holotype}

R54728, 'near east shore of Useless Inlet, $29 \mathrm{~km} \mathrm{NW}$ of Carrarang, WA (26 $\left.18^{\circ} \mathrm{S}, 113^{\circ} 21^{\prime} \mathrm{E}\right)$ ', G. Harold and M. Peterson, 19 August 1976.

\section{Paratypes (15)}

R26683, 10 km SW Carrarang, WA; R39019, R54839, False Entrance Well, WA; R39032-35, south end of Bellefin Prong, WA; R54726-27, $10 \mathrm{~km} \mathrm{NW}$ Useless Loop, WA; R54735-36, 1 km E Editharra Well, WA; R54872, 10 km NW Useless Loop, WA; R54822, 7 km NW Useless Loop, WA; R54890, 3 km SW False Entrance Well, WA; R55031, Catfish Bay Well, WA.

\section{Current status and nomenclature}

Ctenophorus butlerorum, see Melville et al. (2008) for generic placement, Storr et al. (1983) for specific status and remarks below for amendment of species epithet.

\section{Remarks}

The ending of the species epithet has been emended to reflect the collective of people for which the species was named. The latin suffix $-i$ is a masculine genitive used to commemorate a single male person; however, under Remarks, Storr (1977) stated 'This subspecies is named after Mr and Mrs W.H. Butler'. Therefore, in accordance with the Code (International Commission on Zoological Nomenclature 1999), the appropriate suffix would be -orum which is a genitive plural used to commemorate two or more persons sharing the same family name, in this case $\mathrm{Mr}$ and Mrs Butler, thus emending the name to butlerorum. Melville et al. (2008) recognised the error relating to the species epithet; however, chose not to amend it based on their interpretation of relevant Articles of the Code. In accordance with Article 34.2 of the Code, the species epithet is amended here to butlerorum. 


\section{Amphibolurus pictus salinarum Storr, 1966}

Storr, G.M. (1966) The Amphibolurus reticulatus species-group (Lacertilia, Agamidae) in Western Australia. Journal of the Royal Society of Western Australia 49: 17-25 [18].

\section{Holotype}

R17649, 'Norseman, WA (32¹0'S, 12146'E)', G.M. Storr, 2 December 1962.

\section{Paratypes (33)}

R283, R176534 (formerly part of R283), Balladonia, WA; R4679, Kulin, WA; R6443, Kurrawang, WA; R12091-92, [5 km N Point Malcolm] between Israelite Bay and Cape Arid, WA; R13409a, R13409b (now R176535), R13409c*, R176535 (formerly R13409b), Kalgoorlie district [Kalgoorlie Primary School], WA; R14231, Bullock Jinna, $10 \mathrm{mi}$ [16 km] S Cowarna Downs, WA; R14879, 12 mi [19 km] SE Yalgoo, WA; R17351, Newman Rock, 27 mi [44 km] ESE Fraser Range, WA; R18478, R19240, R21533, Lake Varley, WA; R19015, Waeel, WA; R19016-22, Norseman district, WA; R19026, Lake Throssell, WA; R19029, Cundeelee, WA; R19252, Newman Rock, 27 mi [44 km] ESE Fraser Range, WA; R19253, Newman Rock, 27 mi [44 km] ESE Fraser Range, WA; R20535-36, 12 mi [19 km] SE Yalgoo, WA; R20537-38, Lake Anneen, Nannine, WA; R21292, Wagga Wagga, WA; R21293, R22280-81, $12 \mathrm{mi}[19 \mathrm{~km}] \mathrm{SE}$ Yalgoo, WA.

\section{Current status}

Ctenophorus salinarum, see Storr et al. (1983) for generic placement and specific status.

\section{Remarks}

There are two specimens associated with the registration $\mathrm{R} 283$, one a specimen of $C$. salinarium and the other a Ctenophorus sp. specimen. The Ctenophorus sp. specimen has been registered as R176534, both are maintained as paratypes of $C$. salinatium. One registration, R13409, includes three specimens, suffixed a-c; however, only two specimens bearing the tag R13409 could be located. Of the two specimens, the smaller of the two has been reregistered as R176535. The third specimen associated with the registration number R13409 could not be located and is presumed lost. Only two specimens were previously sighted in audits dating back to November 1998 and the third is presumed to have been lost prior to that.

\section{Amphibolurus yinnietharra Storr, 1981}

Storr, G.M. (1981) Three new agamid lizards from Western Australia. Records of the Western Australian Museum 8(4): 599-607 [602].

\section{Holotype}

R51675, '5 km E of Yinnietharra, WA (244ㄴ' $\left.116^{\circ} 13^{\prime} \mathrm{E}\right)^{\prime}, \mathrm{M}$. Peterson, 3 October 1975.

\section{Paratypes (12)}

R47704-06, R52042-45，R56860，25 km SW Yinnietharra, WA; R51674, R51739-41, 5 km E Yinnietharra, WA.

\section{Current nomenclature}

Ctenophorus yinniethara, see Storr et al. (1983).

\section{Ctenophorus nguyarna Doughty, Maryan, Melville \& Austin, 2007}

Doughty, P., Maryan, B., Melville, J. and Austin, J. (2007) A new species of Ctenophorus (Lacertilia: Agamidae) from Lake Disappointment, Western Australia. Herpetologica 63(1): 72-86 [75].

\section{Holotype}

R157979, 'Savory Creek Mouth, Lake Disappointment,

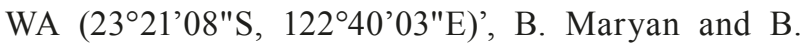
Budrey, 14 September 2004.

\section{Paratypes (11)}

R126970, nr Onegunyah Rockhole, Lake Disappointment, WA; R157970-72, Lake Views, Lake Disappointment, WA; R157973-78, north-western tip Lake Disappointment, WA; R157980, Savory Creek Mouth, Lake Disappointment, WA.

\section{Remarks}

Liver sample of holotype and 10 paratypes (R157970$78, \mathrm{R} 157980)$ stored frozen $\left(-75^{\circ} \mathrm{C}\right)$ at the WAM.

\section{Diporiphora adductus Doughty, Kealley \& Melville, 2012}

Doughty, P., Kealley, L. and Melville, J. (2012) Taxonomic assessment of Diporiphora (Reptilia: Agamidae) dragon lizards from the western arid zone of Australia. Zootaxa 3518: 1-24 [17].

\section{Holotype}

R141589, '2 km west of Bullara Homestead, WA (22 40’23"S, $\left.114^{\circ} 00^{\prime} 58^{\prime \prime} \mathrm{E}\right)^{\prime}$, B. Bush and B. Maryan, 22 June 2000.

\section{Paratypes (4)}

R71582, $4 \mathrm{~km} \mathrm{~N}$ of Mia Mia High School [in error, HS], WA; R129009, R140984, Urala Stn, WA; R157296, Yanrey Stn, WA.

\section{Remarks}

Liver sample of holotype and three paratypes (R129009, R140984, R157296) stored frozen $\left(-75^{\circ} \mathrm{C}\right)$ at the WAM. Additional heart sample of one paratype (R129009) also stored frozen $\left(-75^{\circ} \mathrm{C}\right)$ at WAM. 


\section{Diporiphora albilabris albilabris Storr, 1974}

Storr, G.M. (1974) Agamid lizards of the genera Caimanops, Physignathus and Diporiphora in Western Australia and Northern Territory. Records of the Western Australian Museum 3(2): 121-146 [133].

Holotype

R43517, 'Mitchell Plateau, WA (1448'S, 12550'E)', D.J. Kitchener, 7 September 1971.

\section{Paratypes (18)}

R13780, R41871-72, Kalumburu, WA; R28193, King Edward River, WA; R41870, R42938, Crystal Creek, WA; R43167-69, R43212, R43343, R43515-16, R43532, R43534-37, Mitchell Plateau, WA.

\section{Current status}

Diporiphora albilabris, see Melville et al. (2019).

\section{Diporiphora albilabris sobria Storr, 1974}

Storr, G.M. (1974) Agamid lizards of the genera Caimanops, Physignathus and Diporiphora in Western Australia and Northern Territory. Records of the Western Australian Museum 3(2): 121-146 [135].

\section{Holotype}

R23180, '35 km SE of Pine Creek, NT (1404'S, $\left.131^{\circ} 58^{\prime} E\right)^{\prime}$, G.M. Storr and A.M. Douglas, 12 September 1964.

\section{Paratypes (3)}

R23181, 35 km SE Pine Creek, NT; R23182, 35 km SE Pine Creek, NT; R37133, 72 km SSE Darwin, NT.

\section{Current status}

Diporiphora sobria, see Melville et al. (2019).

\section{Diporiphora bilineata margaretae Storr, 1974}

Storr, G.M. (1974) Agamid lizards of the genera Caimanops, Physignathus and Diporiphora in Western Australia and Northern Territory. Records of the Western Australian Museum 3(2): 121-146 [143].

\section{Holotype}

R27648, 'Kalumburu, WA (14²18'S, $\left.126^{\circ} 30^{\prime} \mathrm{E}\right)$ ', W.H. Butler, 8 July 1965.

\section{Paratypes (10)}

R13600*, Kalumburu, WA; R28194, R28223, King Edward River, WA; R41869, Crystal Creek, WA; R42942, New York Range, WA; R43865, R43881*, R43882*, R43883*, Kalumburu, WA; R43960, Anjo Peninsula, WA.

\section{Current status \\ Diporiphora margaretae, see Melville et al. (2019).}

\section{Remarks}

Twenty-seven additional paratypes held in the SAMA collection (SAMA R2848, R13483A-Z). Four paratypes have been gifted to other museums, three to AMS on 1 November 1973 (R43881-83) and one to FMNH 20 November 1973 (R13600).

\section{Diporiphora convergens Storr, 1974}

Storr, G.M. (1974) Agamid lizards of the genera Caimanops, Physignathus and Diporiphora in Western Australia and Northern Territory. Records of the Western Australian Museum 3(2): 121-146 [133].

\section{Holotype}

R42931, 'Crystal Creek, WA (14³0'S, 12547'E)', N. McNally and C. Pollett, May 1972.

\section{Diporiphora gracilis Melville, Smith Date, Horner \& Doughty, 2019}

Melville, J., Smith Date, K.L., Horner, P. and Doughty, P. (2019) Taxonomic revision of dragon lizards in the genus Diporiphora (Reptilia: Agamidae) from the Australian monsoonal tropics. Memoirs of Museum Victoria 78: 23-55 [46].

\section{Holotype}

R177291 (formerly NMV D75540), 'FairfieldLeopold Downs Road, south of Gibb River Rd, WA (17²9’37.0"S, $\left.125^{\circ} 2^{\prime} 17.7^{\prime \prime E}\right)^{\prime}$, P. Oliver, 2 November 2013.

\section{Paratypes (3)}

R163503-04, Mornington Stn, WA; R177952 (formerly NMV D75542), Fairfield-Leopold Downs Road, south of Gibb River Rd, WA.

\section{Remarks}

Two additional paratypes held at NMV (NMV D75541, D73901).

\section{Diporiphora lalliae Storr, 1974}

Storr, G.M. (1974) Agamid lizards of the genera Caimanops, Physignathus and Diporiphora in Western Australia and Northern Territory. Records of the Western Australian Museum 3(2): 121-146 [138].

\section{Holotype}

R23030 [in error, R23020], 'Langey Crossing, WA $\left(17^{\circ} 39^{\prime} \text { S, } 123^{\circ} 34^{\prime} E\right)^{\prime}$, G.M. Storr and A.M. Douglas, 2 September 1964. 


\section{Paratypes (20)}

R4014, between Wells 39 and 51, Canning Stock Route, WA; R21424-27, R21436-39, 10 km E Tennant Creek, NT; R23012-13, Langey Crossing, WA; R24176*, Elliott, NT; R24200, Helen Springs, NT; R24203-04, $11 \mathrm{~km}$ S Banka Banka, NT; R24234-35, $40 \mathrm{~km} \mathrm{~N}$ Tennant Creek, NT; R24265, 40 km S Tennant Creek, NT; R32135-36, St George Range, WA.

\section{Remarks}

The holotype registration number presented by Storr is in error, the specimen associated with R23030 is a Ctenophorus isolepis isolepis from $5 \mathrm{~km}$ NW Liveringa, WA. Only three specimens from the locality of Langley Crossing are held in the WAM collection (R23012-13, R23020), of which two are listed as paratypes for the species (R23012-13) and the third (R23020) is considered to be the correct holotype desired by Storr to represent the species. The error appears to be a minor typographical error in the registration numbers with 23020 replaced with 23030. In a recent revision of the northern Australian Diporiphora, Melville et al. (2019) referred to the corrected holotype registration for the species. One paratype (R24176) could not be located and is presumed lost. The specimen was previously sighted during a type audit undertaken between July 2008-February 2010. Additional paratypes held in other collections: eight at SAMA (SAMA R3536, R4824A-C, R5047, R5352, R13539A-B) and three at NMV (NMV D2691, D2695, D2914).

\section{Diporiphora linga Houston, 1977}

Houston, T.F. (1977) A new species of Diporiphora from South Australia and geographic variation in D. winneckei Lucas \& Frost (Lacertilia: Agamidae). Transactions of the Royal Society of South Australia 101: 199-205 [203].

\section{Paratypes (2)}

R24529-30, 23 mi (37 km) ENE Wirrulla, SA.

\section{Remarks}

Holotype stored in at SAMA; R15020F, from ' $23 \mathrm{~km}$

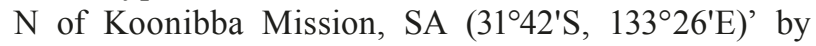
C. Houston, T. Houston, A. Edwards and J. Herridge, collected between 11-13 November 1975. Additional paratypes held in other collections: 48 at SAMA (SAMA R10822-26, R14447, R14459A-B, R14885, R14978A-I, R14998A-L，R15020A-E，R15020G-H，R15174, R15208A-G, R15220, R15600-01) and one at AMS (AMS R54626).

\section{Diporiphora magna Storr, 1974}

Storr, G.M. (1974) Agamid lizards of the genera Caimanops, Physignathus and Diporiphora in Western Australia and Northern Territory. Records of the Western Australian Museum 3: 121-146 [137].

\section{Holotype}

R42786, 'Old Lissadell, WA (16³0'S, 12841'E)', D.J. Kitchener, 19 October 1971.

\section{Paratypes (77)}

R11778, Lissadell, WA; R23126, 37 km SE Kununurra, WA; R23787, R23788, Maranboy, NT; R24115-20, R24142-43, Larrimah, NT; R26788, Grotto Creek, WA; R28228, 29 km N King Edward River, WA; R37108, Mataranka, NT; R40305, Wearyan River crossing, NT; R40479, R40495, Kalumburu, WA; R40723 (in error, R42723), R40724 (in error, R42724), R40760* (in error), R40761* (in error), R40762* (in error), R40763* (in error), R40764* (in error), R40765* (in error), R40766* (in error), R40767* (in error), R40768* (in error), R40769, R40770-71, R40782, R41867-68, Durack River Crossing, New York Range, WA; R42676-79, R42680*, R42698, R42703, R42710-13, R42719, R42726, R42737, R42741-42, R42744, R42746, R42918, R42923*, Lake Argyle, WA; R43547, Kalumburu, WA; R43550-58, Pago, WA; R43862, Lake Argyle, WA; R43867*, R43868*, R43872*, R43873*, R43874*, R43875*, R43876*, R43877*, R43878*, R43879*, R43880*, Kalumburu, WA.

\section{Remarks}

The type location is now currently completely submerged below Lake Argyle. Two paratype registration numbers presented by Storr are in error, R40723-24; R40723 is associated with a specimen of Cryptoblepharus metallicus (Scincidae) from Red Lily Lagoon, Daly River, NT and R40724 is a specimen of Litoria sp. (Pelodryadidae) from Tunnel Creek, WA. The correct registration numbers for specimens of Diporiphora magna matching the localities provided by Storr are R42723-24, respectively. Nine paratypes listed by Storr are in error; R40760-65 are specimens of Gehyra kimberleyi (Gekkonidae) from Old Lissadell, Ord River [now Lake Argyle], WA, R40766 is a specimen of Heteronotia binoei (Gekkonidae) from Old Lissadell, Ord River [now Lake Argyle], WA and R40767-68 are specimens of Ctenotus militaris (Scincidae) from c. $22 \mathrm{~km} \mathrm{~S}$ Ord River Dam, WA. Examination of hardcopy WAM herpetological registers revealed the D. magna paratypes were not the original specimens assigned the registration number. No additional specimens that would have been available to Storr at the time of description matching the localities listed could be identified in the current WAM collection and all nine specimens are presumed lost.

Additional paratypes held in other collections at the time of description (Storr 1974); 18 at NMV (NMV D5095, D5097, D5124, D5179-92, D10085), one at SAMA (SAMA R8167) and one at NTR (NTR 203, now ANWC R738). Thirteen WAM paratypes were gifted to other museums on 1 November 1973, prior to publication of the species descriptions; 11 to AMS (R42923, R43867-68, R43872-80), one to SAMA (R43879) and one to FMNH (R42680). 


\section{Diporiphora pallida \\ Melville, Smith Date, Horner \\ \& Doughty, 2019}

Melville, J., Smith Date, K.L., Horner, P. and Doughty, P. (2019) Taxonomic revision of dragon lizards in the genus Diporiphora (Reptilia: Agamidae) from the Australian monsoonal tropics. Memoirs of Museum Victoria 78: 23-55 [52].

\section{Holotype}

R177292 (formerly NMV D73853), 'Mitchell Plateau, WA (14² $\left.49.45^{\prime} \mathrm{S}, 125^{\circ} 42.12^{\prime} \mathrm{E}\right)^{\prime}$, J. Melville, 12 September 2005.

\section{Diporiphora paraconvergens Doughty, Kealley \& Melville, 2012}

Doughty, P., Kealley, L. and Melville, J. (2012) Taxonomic assessment of Diporiphora (Reptilia: Agamidae) dragon lizards from the western arid zone of Australia. Zootaxa 3518: 1-24 [20].

\section{Holotype}

R163948, '23 km north-east of Warrawagine Homestead, Pilbara Biodiversity Survey quadrat PHYE01, WA (2041'54"S, 12051'23"E)', J.K. Rolfe, A.H. Burbidge and T. Rolfe, 6 October 2006.

\section{Paratypes (6)}

R63525, 2 km NNE of Murguga, Well 39, Canning Stock Route, WA; R131073, Kiwirrkurra, WA; R133348, R133475, Lake Mackay, WA; R137921, Telfer, WA; R164250, Mina Mina Clutterbuck Hills, Gibson Desert, WA.

\section{Remarks}

Liver sample of holotype stored in $100 \%$ ethanol at WAM. Liver sample of five paratypes (R131073, R133348, R133475, R137921, R164250) and additional heart sample of two (R131073, R137921) stored frozen $\left(-75^{\circ} \mathrm{C}\right)$ at the WAM.

\section{Diporiphora perplexa \\ Melville, Smith Date, Horner \& Doughty, 2019}

Melville, J., Smith Date, K.L., Horner, P. and Doughty, P. (2019) Taxonomic revision of dragon lizards in the genus Diporiphora (Reptilia: Agamidae) from the Australian monsoonal tropics. Memoirs of Museum Victoria 78: 23-55 [37].

\section{Holotype}

R177290 (formerly NMV D73819), 'Gibb River $\mathrm{Rd}, 20 \mathrm{~km}$ west of Ellenbrae Station, WA (15 57.31'S, 12652.9'E)', J. Melville, 9 September 2005.

\section{Paratypes (4)}

R119719, Emma Gorge, Cockburn Range, WA; R162517, 25 km S Wyndham, WA; R171418, Prince Regent River NP, WA; R175785, Waterfall Yard, 15 km N Mt Elizabeth HS, WA.

\section{Remarks}

Heart and liver samples of one paratype (R119719) stored frozen $\left(-75^{\circ} \mathrm{C}\right)$ and liver of three (R162517, R171418, R175785) stored in 100\% ethanol at the WAM. Four additional paratypes held at NMV (NMV D73805, D73841, D73978, D73980).

\section{Diporiphora pindan Storr, 1979}

Storr, G.M. (1979) Two new Diporiphora (Lacertilia, Agamidae) from Western Australia. Records of the Western Australian Museum 7(2): 255-263 [256].

\section{Holotype}

R58402, ' $5 \mathrm{~km} \mathrm{~N}$ of Coulomb Point, WA $\left(17^{\circ} 18^{\prime} \mathrm{S}\right.$, 122¹0'E)', R.E. Johnstone, 17 April 1977.

\section{Paratypes (56)}

R116 [in error, R166], Streeters Stn, nr Brome, WA; R15185, R20262-64, R20317-29, R26834, Derby, WA; R27638, Injudunah Creek, WA; R32167, 24 km SSE Derby, WA; R36336, 130 km E Broome, WA; R40266, Coulomb Point, WA; R46216, Lagrange, WA; R46463, Beagle Bay, WA; R46661, Derby, WA; R53797-98, R54013-14, R54018-22, R54028-31, R54038, nr Edgar Ranges, WA; R54080, 37 km SSE McHugh Bore, WA; R58403-04, R58405 [in error, R58458], R58406-10, R58461, $5 \mathrm{~km} \mathrm{~N}$ Coulomb Point, WA; R58500, Martins Well, WA; R58503, $5 \mathrm{~km}$ N Coulomb Point, WA; R58514-15, Martins Well, WA; R58516, 5 km N Coulomb Point, WA; R58517, 'Dampier Land', WA; R58605, 28 km ESE Derby, WA.

\section{Remarks}

Two paratype registration numbers presented by Storr are in error, R116 and R58405; R116 is associated with a specimen of Underwoodisaurus milii (Carphodactylidae) from Mooliabeenee, WA and R58405 is a specimen of Amphibolurus gilberti (Agamidae) from $5 \mathrm{~km} \mathrm{~N}$ Coulomb Point, WA. The correct registration numbers for specimens of $D$. pindan matching the localities provided by Storr are R166 and R58458 respectively. One additional paratype held in the NMV collection (NMV D2111).

\section{Diporiphora reginae Glauert, 1959}

Glauert, L. (1959) A new agamid lizard from Queen Victoria Springs, Western Australia. Proceedings of the Royal Zoological Society of New South Wales, 1957-58: 10 [10]. 


\section{Holotype}

R12961, 'Karin Rock, 14 miles [22.5 km] from Cunderlee [Cundeelee] Mission in the Queen Victoria Springs area, WA' $\left(30^{\circ} 41^{\prime}\right.$ S, $\left.123^{\circ} 17^{\prime} E\right)$, W.H. Butler, 23 January 1959.

Paratypes (4)

R12960, R12962-64, Karin Rock, WA.

\section{Diporiphora superba Storr, 1974}

Storr, G.M. (1974) Agamid lizards of the genera Caimanops, Physignathus and Diporiphora in Western Australia and Northern Territory. Records of the Western Australian Museum 3(2): 121-146 [144].

\section{Holotype}

R43178, Mitchell River, WA (14²5'S, $125^{\circ} 50^{\prime}$ E)', L.A. Smith and R.E. Johnstone, 14 January 1973.

\section{Paratypes (9)}

R13576, Kalumburu, WA; R32066, Manning Creek, WA; R41263-64, R41266, Mitchell River, WA; R4395658, Boongaree Is, WA; R43959, Prince Regent River, WA.

\section{Diporiphora valens Storr, 1979}

Storr, G.M. (1979) Two new Diporiphora (Lacertilia, Agamidae) from Western Australia. Records of the Western Australian Museum 7(2): 255-263 [259].

\section{Holotype}

R31009, 'near Tom Price, WA (2245'S, $\left.117^{\circ} 45^{\prime} \mathrm{E}\right)$ ', C. Tideman and R.S. Robinson, December 1968.

\section{Paratypes (8)}

R23970-73, Kumarina, WA; R25135, 3.5 km SE Turee Creek, WA; R52703, R52737-38, Marandoo town-site, WA.

\section{Diporiphora vescus Doughty, Kealley \& Melville, 2012}

Doughty, P., Kealley, L. and Melville, J. (2012) Taxonomic assessment of Diporiphora (Reptilia: Agamidae) dragon lizards from the western arid zone of Australia. Zootaxa 3518: 1-24 [12].

\section{Holotype}

R145536, ' $86 \mathrm{~km}$ south of Port Hedland, WA (21 $\left.{ }^{\circ} 03^{\prime} 36^{\prime \prime} \mathrm{S}, 118^{\circ} 45^{\prime} 00^{\prime \prime E}\right)^{\prime}$, R.J. Teale and colleagues, May 2001.

\section{Paratypes (4)}

R30427, 16 km SW of Port Hedland, WA; R117871, $1 \mathrm{~km} \mathrm{~N}$ of Mundabullangana HS, WA; R161256, $45 \mathrm{~km}$ NE of Whim Creek, WA; R163224, Cape Lambert, WA.

\section{Remarks}

Liver sample of holotype and three paratypes (R117871, R161256, R163224) stored frozen $\left(-75^{\circ} \mathrm{C}\right)$ at the WAM.

\section{Lophognathus horneri Melville, Ritchie, Chapple, Glor \& Schulte, 2018}

Melville, J., Ritchie, E.G., Chapple, S.N.J., Glor, R.E. and Schulte II, J.A. (2018) Diversity in Australia's tropical savannas: an integrative taxonomic revision of agamid lizards from the genera Amphibolurus and Lopognathus (Lacertilia: Agamidae). Memoirs of Museum Victoria 77: 41-61 [54].

\section{Paratypes (3)}

R108806, Calico Springs, Mabel Downs Stn, WA; R131990, R132850 Kununurra, WA.

\section{Remarks}

Holotype held in the NTM collection (NTM R16472) collected from 'Sambo Bore, Wave Hill Station, NT $\left(18^{\circ} 52^{\prime} 48^{\prime \prime S}, 130^{\circ} 40^{\prime} 12^{\prime \prime E}\right)$. Four additional paratypes held in other collections, three at NMV (NMV D72658, D73846, D74687) and one at NHMUK (NHMUK 1946.8.12.73).

\section{Pogona brevis Witten, 1994}

Witten, G.J. (1994) Taxonomy of Pogona (Reptilia: Lacertilia: Agamidae). Memoirs of the Queensland Museum 37: 329-343 [331].

\section{Paratype}

R9856, Longreach, Qld.

\section{Current status}

Junior synonym of Pogona henrylawsoni Wells and Wellington, 1985, see Shea (1995).

\section{Remarks}

Holotype held at QM (QM J32292) from 'Croydon, Qld' $\left(18^{\circ} 13^{\prime} \mathrm{S}, 142^{\circ} 14^{\prime} \mathrm{E}\right)$, collected by D. Milton, June 1977. Additional paratypes held in other collections: four at QM (QM J38735, J38760-61, J46949) and one at NMV (NMV D11164).

Witten (1994) considered the holotype of $P$. henrylawsoni (AMS Field No. 16814) lost and subsequently nominated a specimen of Pogona vitticeps as neotype, placing $P$. henrylawsoni into synonymy with P. vitticeps. Shea (1995) demonstrated that the holotype specimen of $P$. henrylawsoni was not lost, but had been reregistered of 6 April 1985 (AMS R116984, formerly AMS Field No. 16814), and that the specimens was most similar to $P$. brevis and not $P$. vitticeps, indicating the name $P$. henrylawsoni takes priority over $P$. brevis. As the type specimen of $P$. henrylawsoni was never lost, it has retained usage over $P$. brevis as a senior synonym (Shea and Sadlier 1999). 


\section{Tympanocryptis aurita Storr, 1981}

Storr, G.M. (1981) Three new agamid lizards from Western Australia. Records of the Western Australian Museum 8(4): 599-607 [599].

Holotype

R66296, ' $27 \mathrm{~km}$ SSE of Halls Creek, WA (18²7'S, 1265'E)', M.C. Ellis, 4 September 1979.

\section{Paratypes (2)}

R64051-52, 0.4 km W Wolf Creek Meteorite Crater, WA.

\section{Current nomenclature}

Cryptagama autita, see Witten (1984).

\section{Tympanocryptis diabolicus Doughty, Kealley, Shoo \& Melville, 2014}

Doughty, P. Kealley, L., Shoo, L.P. and Melville, J. (2015) Revision of the Western Australian pebblemimic dragon species-group (Tympanocryptis cephalus: Reptilia: Agamidae). Zootaxa 4039(1): 85-117 [100].

\section{Holotype}

R135413, 'Mount Brockman, WA (22¹7'31"S, 117²'23"E)', S. Anstee, 20 November 1998.

\section{Paratypes (5)}

R135411-12, R135454, Mt Brockman, WA; R170204, $53 \mathrm{~km}$ NNW of Tom Price, WA; R170281, $51 \mathrm{~km}$ ESE of Paraburdoo, WA.

\section{Remarks}

Liver sample of holotype and all paratypes stored frozen $\left(-75^{\circ} \mathrm{C}\right)$ at the WAM.

\section{Tympanocryptis fortescuensis Doughty, Kealley, Shoo \& Melville, 2014}

Doughty, P. Kealley, L., Shoo, L.P. and Melville, J. (2015) Revision of the Western Australian pebblemimic dragon species-group (Tympanocryptis cephalus: Reptilia: Agamidae). Zootaxa 4039(1): 85-117 [104].

\section{Holotype}

R158076, '4 km south-south-east of Wanna Wanna

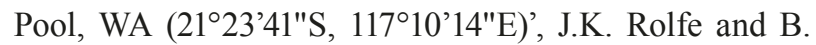
Durrant, 9 October 2004.

\section{Paratypes (5)}

R108817, R113625, 37 km NNE of Auski Roadhouse, WA; R110129, 12 km ESE of Mt Billroth, WA; R121974, Roy Hill Stn, WA; R158074, 4 km SSE of Wanna Wanna Pool, WA.

\section{Remarks}

Liver sample of holotype and three paratypes (R110129, R121974, R158074), and heart sample of two paratypes (R108817, R113625) stored frozen $\left(-75^{\circ} \mathrm{C}\right)$ at the WAM.

\section{Tympanocryptis lineata macra Storr, 1982}

Storr, G.M. (1982b) Taxonomic notes on the genus Tympanocryptis Peters (Lacertilia: Agamidae). Records of the Western Australian Museum 10(1): 61-66 [61].

\section{Holotype}

R44553, '16 km S of main dam at Lake Argyle, WA $\left(16^{\circ} 15^{\prime} \mathrm{S}, 128^{\circ} 40^{\prime} \mathrm{E}\right)^{\prime}$, L.A. Smith and R.E. Johnstone, 20 January 1972.

\section{Paratypes (14)}

R11752, Ord River below main dam, Lake Argyle, WA; R36164, 50 km SE Fitzroy Crossing, WA; R4267275, Old Lissadell, WA; R42728-29, R42734, R42735 [in error, R42733], R44552, Argyle Downs, WA; R60330, 40 km SSW Bullo River HS, NT; R70682, 5 km NNW Mt Percy, WA; R75123, Fitzroy Crossing, WA.

\section{Remarks}

One paratype registration listed by Storr (R42735) is in error, the specimen associated with the number is a Ctenotus inornatus from Lake Argyle, WA. The correct registration associated with a specimen of the species from the locality presented by Storr and available at the time of description is R42733. One additional paratype purportedly held in the MMUS (MMUS 930), from King Sound, WA; however, its current whereabouts is unknown.

\section{Tympanocryptis lineata houstoni Storr, 1982}

Storr, G.M. (1982b) Taxonomic notes on the genus Tympanocryptis Peters (Lacertilia: Agamidae). Records of the Western Australian Museum 10(1): 61-66 [62].

\section{Holotype}

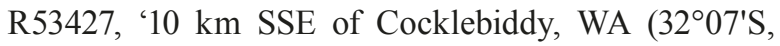
$\left.126^{\circ} 06^{\prime} \mathrm{E}\right)$ ', G. Harold, G. Barron and M. Peterson, 25 April 1976.

\section{Paratypes (61)}

R14184, 16 km NE Fraser Range, WA; R16502, Forrest, WA; R12222, 20 km E Naretha, WA; R15209, Rawlinna, WA; R17418, $20 \mathrm{~km}$ SW Balladonia HS, WA; R19101-04, Naretha, WA; R19105-10, Seymour Downs, WA; R24649, Madura, WA; R25866, 32 km 
E Naretha, WA; R29174-75, Loongana, WA; R28706, 5 km S Loongana, WA; R29335, Forrest, WA; R29656, 3 km W Naretha, WA; R33399, R34022, 95-115 km NNE Rawlinna, WA; R36119, 77 km S Cook, SA; R36475, 95-115 km NNE Rawlinna, WA; R36475* [in error, duplicate registration], 70 km NNE Rawlinna, WA; R37053-54, 95-115 km NNE Rawlinna, WA; R37674, 23 km S Reid, WA; R39711, Kanandah, WA; R41216, 95-115 km NNE Rawlinna, WA; R41225, Kanandah, WA; R41603, 18 km E Loongana, WA; R41646, R4359294, 70 km NNE Rawlinna, WA; R45358, 95-115 km NNE Rawlinna, WA; R45646-47, Toolinna Rockhole, WA; R51804-06, Naretha, WA; R53428-30, 10 km SSE Cocklebiddy, WA; R53756-57, 10 km N Rawlinna, WA; R56883, Toolinna Cave, WA; R66499-500, 7 km NNW Eucla, WA; R66762, 41 km SW Caiguna, WA; R6678992, Toolinna Rockhole, WA; R67249-53, Cocklebiddy, WA; R67261, Mundrabilla, WA.

\section{Current status}

Tympanocryptis houstoni, see Shoo et al. (2008).

\section{Remarks}

In the description under paratypes, Storr states 'For details of 61 specimens in Western Australian Museum from Western Australia and South Australia, see Material'; however, he lists 63 specimens under material, not including the holotype which is not listed. Storr makes reference to 62 specimens in the species description in regards to SVL measurements recorded, ' $\mathrm{N}$ 62' but does not identify which specimens were to be excluded as paratypes or if all material examined was destined to be a paratype. One specimen is listed twice in the material examined section with two different localities, R36475. The correct locality for this specimen is $95-115 \mathrm{~km}$ NNE Rawlinna. No additional specimens of the species matching the locality presented by Storr could be located in the collection.

\section{Tympanocryptis parviceps Storr, 1964}

Storr, G.M. (1964) The agamid lizards of the genus Tympanocryptis in Western Australia. Journal of the Royal Society of Western Australia 47: 43-50 [46].

\section{Holotype}

R16984, 'Eleven miles [17.7 km] south-east of Ningaloo, WA (2248'S, $113^{\circ} 49^{\prime}$ E)', G.M. Storr and B.T. Clay, 18 October 1962.

\section{Paratypes (18)}

R8833, Pt Coates, WA; R10654* (now R177040), R11265* (now R177041), R11266* (now R177042), R11267* (now R177043), R11268* (now R177044), R11269* (now R177047*), R11270* (now R177045*), R13164, Bernier Is, WA; R13221, R13483, Pt Coates, WA; R19095-96, 2 mi [3.2 km] N Ningaloo, WA; R19094, Pt Coates, WA; R19097-98, Quobba, WA; R20494-95, Bernier Is, WA.

\section{Current nomenclature}

Ctenophorus parviceps, see Melville et al. (2008) for generic placement and Melville et al. (2008) for specific status.

\section{Remarks}

Seven paratypes (R10654, R11265-70) listed by Storr are in error, each number is erroneously associated with two specimens, one being the $C$. parviceps specimens designated by Storr and the other being specimens of other species. These errors appear to be attributed to duplicate production and use of metal registration tags made from lead which were individually punched with registration numbers on an as needed basis. Prior to the use of the current pre-printed sequentially numbered wax-free card registration tags, a range of registration tags were used to identify specimens in the collection, predominantly including lead and aluminium metal tags with punched registration numbers and DYMO printed plastic tags, which were all produced on an as needed basis. The past approach of creating registration tags and imprinting registration numbers on them as required has resulted in numerous duplications of registration numbers throughout the herpetology collection..

Entries in early hardcopy specimen registers indicate the correct specimens associated with these registration numbers are not the specimens of Ctenophorus parviceps designated by Storr (R10654 = Demansia psammophis reticulatus (Elapidae), now disposed; R11265 = Pseudechis australis (Elapidae), now disposed; R11266 = Pseudonaja affinis exilis (Elapidae); R11267 = Pseudonaja mengdeni (Elapidae), now disposed; R11268 = Anilios australis (Typhlopidae), now disposed; R11269 = Lialis burtonis (Pygopodidae), $\mathrm{R} 11270=$ Pseudonaja mengdeni (Elapidae), now disposed) and all have been reregistered (see new registration numbers above). Of the seven paratypes with duplicate registration tags, two could not be located and are presumed lost [R11269-70 (now R177047, R177045, respectively)]. Both specimens have not been sighted in previous audits and searches dating back to November 1998, including type audits undertaken between July 2008-February 2010.

\section{Tympanocryptis pseudopsephos Doughty, Kealley, Shoo \& Melville, 2014}

Doughty, P. Kealley, L., Shoo, L.P. and Melville, J. (2015) Revision of the Western Australian pebblemimic dragon species-group (Tympanocryptis cephalus: Reptilia: Agamidae). Zootaxa 4039(1): 85-117 [107].

\section{Holotype}

R154790, '31 km south-west of Doolgunna Homestead, WA (2552’33"S, 11901’41"E), B. Maryan and B. Budrey, 5 April 2004. 


\section{Paratypes (5)}

R114550, $67 \mathrm{~km}$ south of Capricorn Roadhouse, 18 km E Bulloo Down HS, WA; R136459, Norseman Area, WA; R164347, 46.1 km E Leonora, WA; R164350, $11.8 \mathrm{~km}$ E Leonora, WA; R167478, $49.5 \mathrm{~km} \mathrm{~N}$ of Leinster, WA.

\section{Remarks}

Liver sample of holotype and four paratypes (R13649, R164347, R164350, R167478), and heart sample of one paratype (R114550) stored frozen $\left(-75^{\circ} \mathrm{C}\right)$ at the WAM.

\section{ACKNOWLEDGEMENTS}

The author would like to thank José Rosado (MCZ) and Patrick Campbell (NHMUK) for discussions regarding type material of Amphibolurus darlingtoni currently and formerly held in their respective collections, Paul Doughty (WAM) for assistance locating specimens and data regarding agamid type material in the WAM collection.

\section{REFERENCES}

Anonymous (1865). Swan River Mechanics' Institute. Inquirer and Commercial News. 1 February 1865: 3.

Anonymous (1960). A short history of the Western Australian Museum. Western Australian Museum Annual Report 1959-60: 9-10.

Anonymous (1961). Type specimens in the Western Australian Museum (Part 2). Western Australian Museum Annual Report 1960-61: 35-39.

Anonymous (1964). Type specimens in the Western Australian Museum (Part 5). Western Australian Museum Annual Report 1963-64: 38-40.

Anonymous (1966). Type specimens of the Western Australian Museum (Part 7). Western Australian Museum Annual Report 1965-66: 38-42.

Anonymous (1967). Type specimens of the Western Australian Museum (Part 8). Western Australian Museum Annual Report 1966-67: 59-60.

Anonymous (1968). Type specimens of the Western Australian Museum (Part 9). Western Australian Museum Annual Report 1967-68: 62-64.

Badham, J.A. (1976). The Amphibolurus barbatus speciesgroup (Lacertilia: Agamidae). Australian Journal of Zoology 24: 423-443. doi: 10.1071/ZO9760423

Doughty, P., Maryan, B., Melville, J. and Austin, J. (2007). A new species of Ctenophorus (Lacertilia: Agamidae) from Lake Dissapointment, Western Australia. Herpetologica 63: $72-86$.

Doughty, P., Kealley, L. and Melville, J. (2012). Taxonomic assessment of Diporiphora (Reptilia: Agamidae) dragon lizards from the western arid zone of Australia. Zootaxa 3518: $1-24$. doi: $10.11646 / \% 25 \mathrm{x}$

Doughty, P., Kealley, L., Shoo, L.P. and Melville, J. (2015). Revision of the Western Australian pebble-mimic dragon speces-group (Tympanocryptis cephalus: Reptilia: Agamidae). Zootaxa 4039: 85-117.

Ellis, R.J. and Georges, A. (2015). An annotated type catalogue of the turtles (Testudines: Pleurodira: Chelidae) in the collection of the Western Australian Museum. Records of the Western Australian Museum 30(1): 52-60. doi: 10.18195/ issn.0312-3162.30(1).2015.052-060

Ellis, R.J., Doughty, P. and Roberts, J.D. (2017). An annotated type catalogue of the frogs (Amphibia: Anura: Limnodynastidae, Myobatrachidae, Pelodryadidae) in the collection of the Western Australian Museum. Records of the Western Australian Museum 32(1): 1-28. doi: 10.18195/ issn.0312-3162.32(1).2017.001-028

Ellis, R.J. (2018a). An annotated type catalogue of varanid lizards (Reptilia: Squamata: Varanidae) in the collection of the Western Australian Museum. Records of the Western Australian Museum 33(2): 187-194. doi: 10.18195/issn.03123162.33(2).2018.187-194

Ellis, R.J. (2018b). Clarification of the type series of Amphibolurus barbatus microlepidotus Glauert, 1952 (= Pogona microlepidota) (Reptilia: Squamata: Agamidae). Zootaxa 4457: 197-200. doi: 10.11646/zootaxa.4457.1.12

Ellis, R.J., Doughty, P. and Bauer, A.M. (2018). An annotated type catalogue of the geckos and pygopods (Squamata: Gekkota: Carphodactylidae, Diplodactylidae, Gekkonidae, Pygopodidae) in the collection of the Western Australian Museum. Records of the Western Australian Museum 33(1): 51-94. doi: 10.18195/issn.0312-3162.33(1).2018.051-094

Fitzinger, L.J. (1843) Systema Reptilium. Braumüller et Seidel, Vindobonae.

Glauert, L. (1952). Herpetological miscellanea. II. Some new Western Australian lizards. Western Australian Naturalist 3: $168-170$.

Glauert, L. (1959). A new agamid lizard from Queen Victoria Springs, Western Australia. Proceedings of the Royal Zoological Society of New South Wales 1957-58: 10.

Gray, J.E. (1825). A synopsis of the genera of reptiles and amphibia, with a description of some new species. Annals of Philosophy 10: 193-217.

Gray, J.E. (1841) Description of some new species and four new genera of reptiles from Western Australia, discovered by John Gould, Esq. Annals and Magazine of Natural History (Series 1) 7: 86-91.

Gray, J.E. (1842) Description of some hitherto unrecorded species of Australian reptiles and batrachians. Zoological Miscellany 2: 51-57.

Gray, J.E. (1845) Catalogue of the Specimens of Lizards in the Collection of the British Museum. British Museum, London.

Greer, A.E. (1989). The Biology and Evolution of Australian Lizards. Surrey Beatty \& Sons, Chipping Norton.

Houston, T.F. (1977). A new species of Diporiphora from South Australia and geograhic variation in D. winneckei Lucas \& Frost (Lacertilia: Agamidae). Transactions of the Royal Society of South Australia 101: 199-205.

Loveridge, A. (1932). New lizards of the genera Nephrurus and Amphibolurus from Western Australia. Proceedings of the New England Zoological Club 13: 31-34.

Melville, J., Schulte II, J.A. and Larson, A. (2001). A molecular phylogenetic study of ecological diversification in the Australian lizard genus Ctenophorus. Journal of Experimental Zoology 291: 339-353.

Melville, J., Shoo, L.P. and Doughty, P. (2008). Phylogenetic relationships of the heath dragons (Rankinia adelaidensis and $R$. parviceps) from the south-western Australian biodiversity hotspot. Australian Journal of Zoology 56: 159-171. doi: 10.1071/ZO07069 
Melville, J., Haines, M.L., Hale, J., Chapple, S. and Ritchie, E.G. (2016). Concordance in phylogeography and ecological niche modelling identify dispersal corridors for reptiles in arid Australia. Journal of Biogeography 43: 1844-1855. doi: 10.1111/jbi.12739

Melville, J., Ritchie, E.G., Chapple, S.N.J., Glor, R.E. and Schulte II, J.A. (2018). Diversity in Australia's tropical savannas: an integrative taxonomic revision of agamid lizards from the genera Amphibolurus and Lopognathus (Lacertilia: Agamidae). Memoirs of Museum Victoria 77: 41-61. doi: 10.24199/j.mmv.2018.77.04

Melville, J., Smith Date, K.L., Horner, P. and Doughty, P. (2019). Taxonomic revision of dragon lizards in the genus Diporiphora (Reptilia: Agamidae) from the Australian monsoonal tropics. Memoirs of Museum Victoria 78: 23-55. doi: 10.24199/j.mmv.2019.78.02.

Peters, W. (1863) Eine Übersicht der von Hrn. Richard Schomburgk an das zoologische Museum eingesandten Amphibien, aus Buchsfelde bei Adelaide in Südaustralien. Monatsberichte der Königlichen Preussische Akademie des Wissenschaften zu Berlin 1863: 228-236.

Peters, W. (1867) Über Flederthiere (Pteropus gouldii, Rhinolophus deckenii, Vespertilio lobipes, Vesperugo temminckii) und Amphibien (Hypsilurus godeffroyi, Lygosoma scutatum, Stenostoma narirostre, Onychocephalus unguirostris, Ahaetulla poylepis, Pseudechis scutellatus, Hoplobatrachus reinhardtii, Hyla coriacea.). Monatsberichte der Königlichen Preussische Akademie des Wissenschaften zu Berlin 1867: 703-713.

Sabaj, M.H. (2016). Standard symbolic codes for institutional resource collections in herpetology and ichthyology: an online reference. Version 6.5 (16 August 2016). American Society of Ichthyologists and Herpetologists, Washington DC [available at: http://www.asih.org/].

Shea, G.M. (1995). The holotype and additional records of Pogona henrylawsoni Wells \& Wellington, 1985. Memoirs of the Queensland Museum 38: 574.

Shea, G.M. and Sadlier, R.A. (1999). A catalogue of the non-fossil amphibian and reptile type specimens in the collection of the Australian Museum: Types currently, previously and purportedly present. Technical Reports of the Australian Museum 15: 1-92.

Shoo, L.P., Rose, R., Doughty, P., Austin, J.J. and Melville, J. (2008). Diversification patterns of pebble-mimic dragons are consistent with historical disruption of important habitat corridors in arid Australia. Molecular Phylogenetics and Evolution 48: 528-542. doi: 10.1016/j.ympev.2008.03.022

Storr, G.M. (1964). The agamid lizards of the genus Tympanocryptis in Western Australia. Journal of the Royal Society of Western Australia 47: 43-50.

Storr, G.M. (1965). The Amphibolurus maculatus species-group (Lacertilia, Agamidae) in Western Australia. Journal of the Royal Society of Western Australia 48: 45-54.
Storr, G.M. (1966). The Amphibolurus reticulatus species-group (Lacertilia: Agamidae) in Western Australia. Journal of the Royal Society of Western Australia 49: 17-25.

Storr, G.M. (1967). Geographic races of the agamid lizard Amphibolurus caudicinctus. Journal of the Royal Society of Western Australia 50: 49-56.

Storr, G.M. (1974). Agamid lizards of the genera Caimanops, Physignathus and Diporiphora in Western Australia and Northern Territory. Records of the Western Australian Museum 3: 121-146.

Storr, G.M. (1977). The Amphibolurus adelaidensis species group (Lacertilia, Agamidae) in Western Australia. Records of the Western Australian Museum 5: 73-81.

Storr, G.M. (1979). Two new Diporiphora (Lacertilia, Agamidae) from Western Australia. Records of the Western Australian Museum 7: 255-263.

Storr, G.M. (1981). Three new agamid lizards from Western Australia. Records of the Western Australian Museum 8: 599-607.

Storr, G.M. (1982a). Revision of the Bearded Dragons (Lacertilia: Agamidae) of Western Australia with notes on the dismemberment of the genus Amphibolurus. Records of the Western Australian Museum 10: 199-214.

Storr, G.M. (1982b). Taxonomic notes on the genus Tympanocryptis Peters (Lacertilia: Agamidae). Records of the Western Australian Museum 10: 61-66.

Storr, G.M., Smith, L.A. and Johnstone, R.E. (1983). Lizards of Western Australia II. Dragons and Monitors. Western Australian Museum, Perth.

Uetz, P., Freed, P. and Hošek, J. (2019). The Reptile Database. Available at: http://www.reptile-database.org/

Wagler, J.G. (1830) Natürliches System der Amphibien, mit vorangehnder Classification der Säugethiere und Vögel. Gotta'schen, München.

Wells, R.W. and Wellington, C.R. (1983[1984]) A synopsis of the class Reptilia in Australia. Australian Journal of Herpetology 1: 73-129.

Wells, R.W. and Wellington, C.R. (1985). A classification of the Amphibia and Reptilia of Australia. Australian Journal of Herpetology Supplementary Series: 1-61.

White, J. (1790). Journal of a voyage to new South Wales, with sixty-five plates of non descript animals, birds, lizards, serpents, curious cones of trees and other natural productions. Debrett, London.

Witten, G.J. (1984). Relationships of Tympanocryptis aurita Storr, 1981. Records of the Western Australian Museum 11: 399-401.

Witten, G.J. (1994). Taxonomy of Pogona (Reptilia: Lacertilia: Agamidae). Memoirs of the Queensland Museum 37: 329-343.

MANUSCRIPT RECEIVED 23 MARCH 2019; ACCEPTED 18 NOVEMBER 2019. 